\title{
THE INFLUENCE OF CHRONIC SINUSITIS ON THE CAPACITY OF MENTAL WORK
}

Report 4 Influence of Chronic Sinusitis on the Temperment of the Patzent.

\section{K. SHIRAKURA}

\section{From the Otolaryngology Department Shoua Medical Schoal \\ (Drrector: Prof T. Yamamoto)}

The author, investigated the influence of chronic sinusitis on the temperment of patients. The mental capacity was found not to be impaired merely by the presence of the disease. The apparent disturbances of mentalwork of the patient with chronic sinuaitis were considered to be attributable to the lack of power of concentration or the feelung of lassitude caused by the disease.

\section{慢性副鼻腔炎と精神機能との関係}

第 4 編 慢性副鼻腔炎と心情との関係

炤机医科大学耳尊咽晚科教室（主任：山本常市教授）

白倉賢 豆

\section{第 1 章 緒 言}

私は第 1 編，第 2 編，第 3 編に出いて「漫性副具腔炎 患者の智能指数, 精神作業能力の休憩効果率, 向性指数 を通じて智的作業能率を榆した結果，これらの平均值は 健康者の平均值に比して低く，又鼻症状のみを有する慢 性副鼻腔炎患者の前記諸検查の平均値と，健康者のこれ らとの間には統計的に有意の差を見ないが，Aprosexıa を有する漫性副鼻腔炎患者の前記諸検查の平均值は，何 れも健康者のそれに比して低く，統計的にる有意の差を 認め, 又僈性副鼻腔炎患者の術前に哈ける智能指数, 休

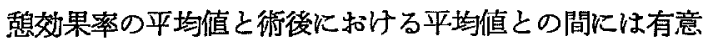
の差を見たが，向性指数は術前，術後に括いて差を見な い」報告したが，本編においては慢性副鼻腔炎患者の 手術後に扣いて，智能指数並に休賏効果率の变化に之し い者 (以下 A 群とする) 及び成續の明らかに上昇せる 者（以下 B 群とする）とに心情検查を施行し，興味あ る成績を得たのて報告する.

\section{第 2 章 実験材料並に実験方法}

付料は国立千葉病院耳鼻咽喉科人院患者で，智能検查 そは田中・B 式を使用 $し$, 棈神作業能力検查は Krae-

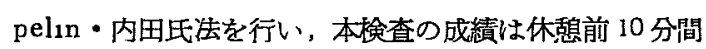
の平均作業量を分母とし，休咊後 5 分間の平均作業量を 分子として、これを 100 倍する休唕效果率て表わし，心 情検查は教育衛生研究所心情質微標検查法を用いた（表 参昭).

第 1 表

\begin{tabular}{|c|c|c|c|}
\hline & 行後知能指数堺加 & 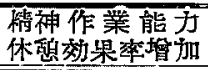 & \\
\hline A & 5 以下 & 5 以下 & 20 例 \\
\hline B & 10 以上 & 10 以上 & 20 例 \\
\hline
\end{tabular}

術後に括ける諸検查は術後 6 力月以上経過し，鼻症状 治瘜の状態にあるむのを用い第 1 表の如く各20 例を選 んて, 術前に比して, 術啳における指数, 休蒩効果率の 增加が 5 以下 (A 群)，10 以上 (B 群) に分湆てみる と，その成績第 3 章の如くである.

\section{第3章 実験成樍}

この検查法で，1ロ八を正常，二示を異常に分け，A 群，B 群を比較すると，その成績は次の通りである(第 1 図, 第 2 表参照). 


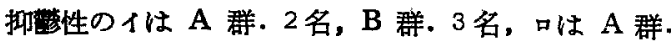
9 名, B 群. 8 名, 心は A 群. 4 名、B 群. 5 名, = は A 群. 4名, B 群. 3 名，小は $\mathrm{A}$ 群. 1名、B 群. !名で，過感性のイは A 群. 3 名，B 群. 3 名。回は A 群. 7 名, B 群. 8 名, 八は A 群. 5 名, B 群. 4 公, 二は $\mathrm{A}$ 群. 4 名, $\mathrm{B}$ 群. 5 名、木は $\mathrm{A}$ 群. 1 名, $\mathrm{B}$ 群. 0 名、にして, 強迫性のイは $\mathrm{A}$ 群. 3 名, B 群. 2 名, 口は $\mathrm{A}$ 群. 7 名, B 群. 6 名, 八は $\mathrm{A}$ 群. 5 名， $\mathrm{B}$ 群. 6 名，二は $\mathrm{A}$ 群. 5 名，B 群。 5 吕，木は $\mathrm{A}$ 群 $\mathrm{D}$ 名, B 君. 1名で, 自己不確実性のイは $\mathrm{A}$ 君 3

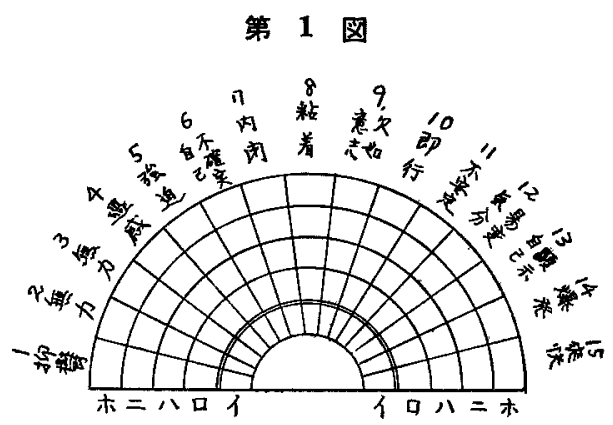

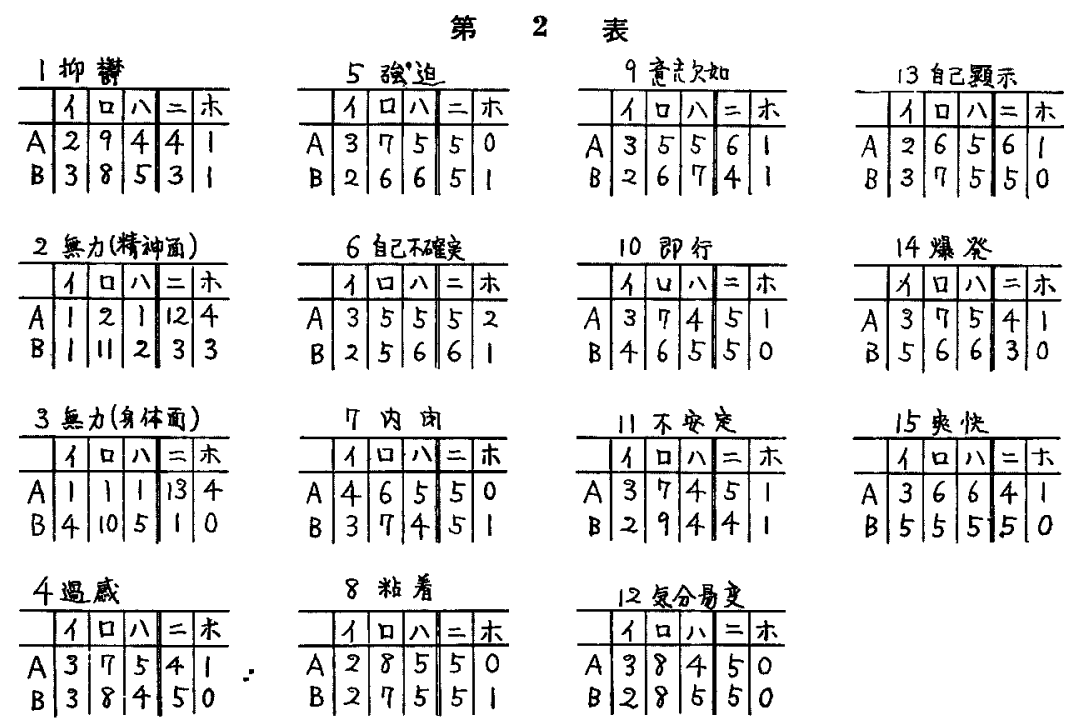

名, B 群. 2 名, 可は A 群 5 名, B 群. 5 名, 八は B 群 0 名て, 不安定性の价 $\mathrm{A}$ 群 3 名, B 群 2 A 群. 5 名, B 群. 6 名, 二はA 群. 5 名, B 群. 6 名. 林 $\mathrm{A}$ 群. 2 名, $\mathrm{B}$ 群. 1名で，内閉性の1は $\mathrm{A}$ 群. 4 名, B 群. 3 名, 口住 A 群. 6 名, B 群。 7 名, 八は A 群. 5 名, B 群. 4 名, =は A 群 5 分, B

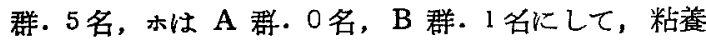
性のイは A 群.2名, B 群. 2名, 口は A 群 8 名, B 辟. 7 名, 八は $\mathrm{A}$ 群. 5 名, B 群 5 名, 二は $\mathrm{A}$ 群 5 名, B 群。 5 名、林 A 群. 0名，B群 1 名て， 意志欠如の1は A 群. 3 名, B 群. 2名, 口は $\mathrm{A}$ 群. 5 名，B 群. 6 名，八はA 群. 5名，B群. 7白= はA 群.6名，B群. 4名。林 $\mathrm{A}$ 群。1名，B群。 1 名沉して, 即行性の1はA 群。3各, B 群. 4名, 口 は $\mathrm{A}$ 群. 7 名, B 群. 6 名, 八は A 群. 4 台, B 群

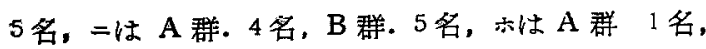
名, 吕は $\mathrm{A}$ 群。7名, $\mathrm{B}$ 群. 9 名, 小性 $\mathrm{A}$ 群. 4 名, B 群. 4 名, 二は A 群. 5 名, B 群。 4名, 木は A 群. 1 名, $\mathrm{B}$ 群 1 名て, 気分易变性の1は A 群. 3 名, $\mathrm{B}$ 群. 2 名, 可は $\mathrm{A}$ 群 8 名, $\mathrm{B}$ 群 8 名, 八は A 群. 4 名, B 群. 5 名, =忙 A 群. 5 名, B 群. 5 名, 小は $\mathrm{A}$ 群. 0 名, 0 名にして, 自己顕示性 のイは $\mathrm{A}$ 群 2 名, B 群 3 名, 口は $\mathrm{A}$ 群. 6 名, B 群. 7名, 八はA 群 5 名, B 群. 5 名, 二小 A 群. 6 名, B 群 5 名, 杖 $\mathrm{A}$ 群 1 名, $\mathrm{B}$ 群 0 名, 爆 発性の1は A 群 3 名, B 群 5名, 口は $\mathrm{A}$ 群 7

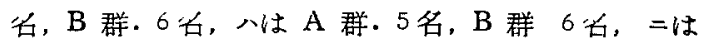
A 群. 4 名, B 群 3 名, 木は $\mathrm{A}$ 群. 1名, B 群。 0 台, 爽快性の1は A 群. 3 台, B 群. 5 名, 口は A 群. 6 台, B 群. 5 名, 八は A 群. 6 名, B 群. 5 名。 
二は A 君 4 名, B 群。5名, 水はA 群。1名、B 群. 0名にして，何れもA 群，B 群の正常，異常の間には 美は見られないが，無力性の皘神的のむのは，1：A 洋 1 名, B 群 1 名 口: A 群. 2名, B 群 11 名, ‥ A 群 1 名, B 群 2 名, = A 群, 12名, B 群 3名，皮、A 群. 4 名、B 群. 3 名で，身体的のもの は、1：A 群 1名, B 群. 4名口 A 群 1 名, B 群 10 名, 八 $\mathrm{A}$ 群, 1 名, B 群 5 名, = A 群 13名、B群. 1名, 办 A 群. 4名, B 群 0 名化 $\tau$ ，正常，異常代分恀て見ると，猜神的のるのは，正常 A 群 4 名, B 群. 14名, 異常 A 群. 16名, B 群 6 名て，身体的のものは，正常 A 群 3 名，B群 19 名, 異常 A 群 17 名, B 群 1 名て, 統計学的に及 ても有意の差を認めた。

\section{第4章考按}

教育衛生研究所式心情質徵標険查で，心情質徴標は抑

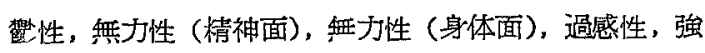
迫性，自己不確実, 内閉性, 粘着性, 意志欠如, 即行 性，不安定性，気分易变性，自己顕示，爆発性，爽快性 の15 K大別されて呿り，この各心情質徽標はイロハニ ホの 5 段階に分けられている. 即ち, 1は反対改標, 口 は普通徵標, 八汢固有徽標, 二は编倚徵標, 䄱異常徽 標とされ，1ロ八を示するのは正常範围内にあるすのて あるが，二小を示するのは異常に性格特徴の強いことを 示するのてあり, 偏倚徽標のあるものは軽度変調, 異常 徵標のあるるのけ高度変調あるものとされている。

さて，前記成績に就て，1口八を正常笨团，二ホを異 常範团とすると，

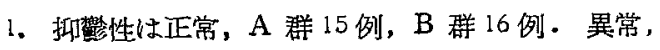
A 群 5 例，B群 4 例

4. 過感性恃正常，A 群 15 例，B 群 15 例：異常， A 群 5 例, B 浮 5 例

5. 強迫性佂常, A 15 例, B 群 14 例. 異常, $A$ 群 5 例, B 列

6. 自己不磪奏は正常, $A$ 群 13 例, B 群 13 例 異 常, $\mathrm{A}$ 群 7 例， B 群 7 例

7. 内閉性は正常，A 群 15 例，B 群 14 例：異常， A 群 5 例, B 群 6 例

8. 枮着性は正常, A 群 15 例, B 群 14 例 - 異常, A 群 5 例, B 群 6 例

9. 意志欠如恃正常, A 群 13 例，B 群 15 例異常， $\mathrm{A}$ 群 7 例, B 群 5 例

10. 即行性江正常, A 群 14 例, B 群 15 例異常,
A 群 6 例, B 群 5 例

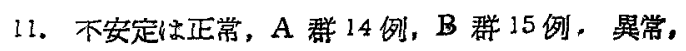
A 群 6 例, B 群 5 例

12. 気分易变怔正常，A 群 15 例，B 群 15 例: 異常， $\mathrm{A}$ 群 5 例, B 群 5 例

13 自己顕示証常, A 群 13 例, B 群 15 例：異常心 $\mathrm{A}$ 群 7 例, B 例

14. 䈋然性性正常, A 君 15 例, B 君 17 例. 罢常, $A$ 群 5 例, B 群 3 例

15. 教快性性正常，A 君 15 例，B君 15 例異常。 A 群 5 例, B 群 5 例

てあつて、これらの心情質徵標については，A 群，B 群の正常, 異常の間には統計学的に有意の美は見られな いが，棈神的無力性及び身体的無力性については，第3 表及び第 4 表の如くてあり，統計学的作も有意の差を認 めた 即ち, 術後の変化の乏しい A 群に扣いては正常 のものが少く，異常な心情を示すものが多く，術後の成 㺓の良くなつた B 群に叔いては正常範囲のものが多く， 異常に入るるのが少い.この事恃精神的無力性及び身体 的無力性何机にも共通している。

\begin{tabular}{|c|c|c|}
\hline & イロ八 & $=\pi$ \\
\hline A & 4 & 16 \\
\hline B & 14 & 6 \\
\hline
\end{tabular}

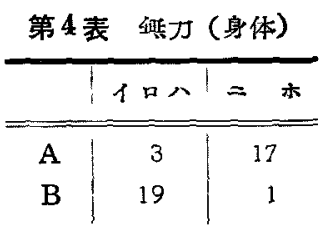

䑤力性の心情とは，身体的あるいは精神的沉不全感 (Insuffizieuzgefuhl)，心気性 (Hypochondrie)，を持 つものて，所謂慢性神経敦弱，又は神経質の母体をなす るのてあるが，前記検查成績に依れば著しく無力性のる の, 即ち強い心不全感乃至心気性を有するるのは慢性副

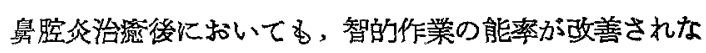
い. 若し漫性副鼻腔炎か一次性潪的能力低下させる とすれば，情意的特性のいかん加つわらず，曼性副悬

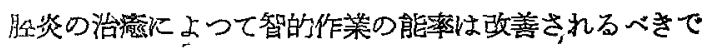
あって，上記の結果は一見不可解な現象の如くである。

しかしこのことは棈神作業能率の低下が漫性副鼻腟 矢㢈患による心因性のあるいは外因反応の最る mild な形としての過敏性倩動 衰弱状態 (hyperasthetische emotınelle schwachezustande) の結果としての心身 不全咸，心受性に起因すると考えれば容易に説明できる のてあつて，心身不全感，心気性即ち無力性の棈神態度

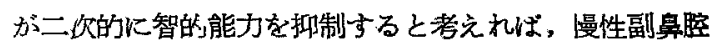


炎治满後も猶不全感，無力性を残しているるの，即ち恐 らくは生来の無开性性格異常者（Kuri Schneıder の所 謂 asthenische Psychopathen) ては，術後検查成績 が改善されたいのが当然てある。

以上の事実よりみれば，慢性副鼻腔炎が一次性の智的 能力を低下せしむると考えるのは罢りであることが明か であるが，更に智的作菜率の減退の主因てある無力性の 精神態度は心因性の要素が，外因性のそれより大てある

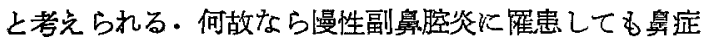
状のみを呈し，精神的苦訴のないものもあり，か小る例 では智的作業の検查成柱が正常人と異らないことは前麻 の如くであり，又漫性副舅腔炎そのものの重篤度と精神 的苦訴の強さとは必ずしも平行しないからてある。

\section{第 5 章 結論}

1) 慢性副鼻胫炎手術後において，智能指数，精神作 業能力の 休憇効果率の 増加が 5 以下の者，10以上の者 各例に就て心情質徵標検查を施行した

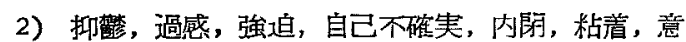

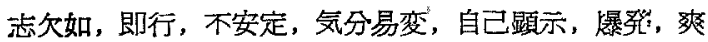
快性については，A 群，B 群の間に圭異は見られない.

3）無力性の身体的のものは正常範团のbの.A 群 3 例，B 群 19 例，暴常に著明の8の：A 群 17 例，B 群 1 例にして, 精神的の6のは正常. A 磁 4 例，B 在 14 例，異常 A 群 16 例，B 群6例てあつた

4) 慢性副鼻腔炎患者の心情調查の結果，慢性副鼻腔 炎は患者の智的作業能力を一次性に減退させるむのては なく，それは慢性副鼻题火によつて起る舞力性の精神態 度即ち心身の不全感，心気性に原因していると推考し た。

\section{文献}

1) Allport, G.: Personality 1937. 2) Murphy, HA.: Personality 1951.

3) Kretchmer, E.:

Korperban und charakter, 12, Aufl, 1936. 4) Kretchmen, E.: Medızınısche psycho'ogy, 4te Auf,

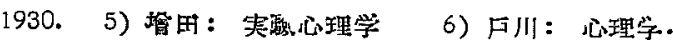
7）横田. サレペリン・玄田槜神作業検登法. 8) 石 川：智能検查法指釬. 9) 森：平㮢利 22, (1), 1950. 10) 鈖木, 平林 耳喉利, 23, (11), 1951 . 11）鈴禾，平朴：耳喉利，23，(12), 1951. 12）鈖 不, 平林 耳喉科, $24,(1), 1952$ 13) 神日 耳喉科，24，(3), 1952 14) 祭 耳喉科，24， (9), 1952. 15) 早川：日耳.会, 49, 1943. 16) 市原：日7会. 55，(1)，1949 17）吉行，枟尾： 福岡医誌，28. 18）市原 耳犊科，25，(6)，1953. 19）市原：耳啒科，25，(9)，1953，20）本林：日 耳会，57，(3)，1951. 21）市原 日本医穿新坏， 1637. 22) 市原。耳吅索利, 26, (1), 1954. 23) 市原：日耳会，58，(2)，1952。24）市原 日开

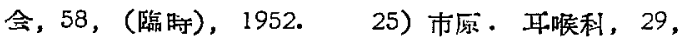
(1), 11957, 26) 平休 日耳会, 59, (6), 1953.

本誦交の要旨保第 57 回日本工番叫喉利学会 総会にてちいて発交した.

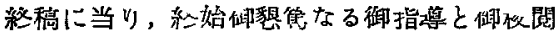
を賜つた恩耍山本教授並に一本学精神利学教室塩 崎教授に深謝すると共に，湖助力を頂いた市原 助教授に感衡の澺を唁する。

（原和到菟 $=$ 诏和 34.2.11 日一急載） 